\title{
THE ISLAMIC TRADITION OF BAKUMPAI DAYAK PEOPLE
}

\author{
Nasrullah \\ Lambung Mangkurat University, Banjarmasin
}

\begin{abstract}
This paper presents the dilemma of an ethnic group which is influenced by the views from the outside as well as the inside with regard to the dominance of religious identity. Specifically, this paper discusses the existence of Bakumpai and the Bakumpai people as part of the Dayak tribes and their Islamic practice. This article is expected to provide understanding of religious diversity in an ethnic group particularly the Dayak and how it influences the Dayak culture.
\end{abstract}

Keywords: Bakumpai, Dayak, Islamic Tradition

\section{INTRODUCTION: CURRENT MISUNDERSTANDING}

The majority of Indonesia's population are Muslims. This fact does not necessarily limit the existence of other minority religions in Indonesia, such as Christianity Protestantism, Catholicism, Hinduism, Buddhism and Confucianism. However, a similar presumption does not occur when viewing the presence of religions in an ethnic group. Whether we realize it or not, there is a tendency of labelization that a religion is identical to a particular ethnic group. In fact, humans are born without the power to determine their own identity or choose their ethnic group or religion, for example, because they often follow a religion embraced by their parents. Similarly, Islam as a religion of the majority in Indonesia, if correlated to the dominant religion embraced a particular group, it could become a religion of the minority.

Current religious issues commonly presumed of the ethnic Dayak is that they are synonymous with Christians, or if they have converted to Islam, they no longer call themselves Dayak as they are most likely referred to as Malay. In fact, there are Muslim sub-ethnic Dayak such as Bakumpai, Ngaju, Tidung, etc. However, to exclusively categorizing sub-ethnic Dayaks into Muslim community is also not always right because they are not only Muslims and Christians, but they also had their own local religion called Kaharingan far before Islam and Christianity were introduced to them (see Mahin, 2009: 213). To continue this discussion will certainly be complicated so it needs to be limited. Therefore, the author will focus only on two things in an effort to straighten out any misunderstanding that a particular ethnic group is 
synonymous with a certain religion anyway. First, with regard to the lives of Muslims a minority in Indonesia in the context of ethnicity i.e. the Muslim Bakumpai amid the majority Dayak who are considered non-Muslims. Second, people of a particular ethnic group cannot immediately be part of a certain religion that is identical with it as in the case of the adherents of Islam among ethnic Dayak Bakumpai.

\section{BAKUMPAI, PART OF THE ETHNIC DAYAK}

Bakumpai as part of Dayak ethnic group can be viewed from the larger group, to smaller group to find the position of the Bakumpai. The ethnic Dayak is divided into seven major groups, namely: (1) Dayak Ngaju, (2) Dayak Apu Kayan, (3) Dayak Iban and Heban or Dayak Laut, (4) Dayak Klemantan or Dayak Darat; (5) Dayak Murut; (6) Dayak Punan, and (7) Dayak Ot Danum. Each of the seven sub-groups are divided into tens to hundreds of smaller ethnic groups of Dayak. Dayak Ngaju, in particular, the first group, can be divided into four major tribes, namely: Ngaju, Maanyan, Lawangan and Dusun. Each of the Ngaju Dayak is divided up into dozens of groups, and one of them is Dayak Bakumpai (Riwut, 1993). According to another version, the ethnic Dayak Bakumpai is seventh group of the Dayak Ot Danum that has 68 smaller tribes, which in addition to Bakumpai includes Ngaju, Kapuas, Kahayan, Katingan, Sampit, Seruyan (Riwut, 1993: 267).

The difference version of the Bakumpai as part of the Ngaju Dayak and from Ot Danum Dayak, has no specific explanation from Tjilik Riwut. However, looking at the meaning of the word Ot Danum and Ngaju, they turn out to have similar meanings. The word $O t$ means upstream; danum means water. So, Ot Danum means Upstream River, which refers to people who live in the upstream of the river. Meanwhile Ngaju comes from the word Bi-aju meaning $B i=$ from, $a j u=$ interior, so Bi-aju means of the interior part (Riwut, 1993: 262). Ot Danum and Ngaju have similar notion in terms of the meanings of the words are in the upper reaches of the River. Perhaps Tjilik Riwut (researcher) indirectly wanted to show the Dayak territory of Ot Danum and Ngaju which are situated on the riverside area. This indicates that the Bakumpai Dayak is part of either Ngaju or Ot Danum.

Other opinions about ethnic Dayak Bakumpai is that they come from one of the Kahayan sub-groups, presumably from a village whose name is Bakumpai on the upper Barito River. They spread to inhabit the southern part of the Barito River, into the Kahayan River, and Mentaya Sampit to Tumbang Samba (Kasongan), Central Kalimantan (Maulani, 2000: 141). Of the opinions above, there may be differences in the genealogy of the Bakumpai as part of the ethnic 
Dayak. However, researchers have shown that the ethnic Bakumpai is part of the Dayak living in the region of the Barito River.

In terms of the language used, the Bakumpai is certainly more understandable by people of Dayak Ngaju, Maanyan, Kapuas, and Kahayan; and that is one of the reasons they are called the Dayak. Sometimes these sub-groups speak in their own language and seem to be totally undisturbed in communication since both speakers can mutually understand (Ibrahim, et al, 1979). As for the discussion of the Bakumpai people in this article, it is taken from the author's research in the village of Jambu Baru, sub-district of Kuripan, Kuala Barito District, in South Kalimantan province. The village is located on the bank of the Barito river bordered by Central Kalimatan on the upstream area and by South Kalimatan on downstream area to the mouth of the Barito River. The Villagers of Jambu Baru are the community of Dayak Bakumpai, and they still preserve the tradition and language of Bakumpai.

\section{THE ORIGIN OF THE PRACTICE OF ISLAM AMONG BAKUMPAI PEOPLE}

The trace of the arrival of Islamic teachings to the Bakumpai people in the area of Barito Kuala District is viewable from two possibilities. First, through trade, which was very common for the spread of Islam in the archipelago by the Arabs traders. Marabahan, the capital city of the District of Barito Kuala, in the past was the Banjar Kingdom trade center. The trade was not conducted by local traders only, but a lot of international traders also came to Marabahan (Sjamsuddin, 2001; Maulani, 2000). This fact may indicate that Islam entered through the trade route of international trade center mentioned.

The second possibility is based on the political changes happening in the Banjar Kingdom in the 17th century. When Prince Tumenggung refused to give the throne to the legitimate heir, Prince Samudera (the nephew of Prince Tumenggung), it caused a civil war between the two. Prince Samudera asked for help from the Kingdom of Demak. However, there was an agreement between the Prince Samudera and the Kingdom of Demak. Its content was that if the Demak troops won the battle against his uncle Prince Tumenggung, the Banjar people and its King would embrace Islam.

Regardless of which of the two possibilities above is true, Bakumpai people converted to Islam before there was an agreement between the Kingdom of Banjar and Demak. Clearly the spread of Islam to the Bakumpai people along the Barito River was made possible by H. Abdussamad. He was the grandson of Sheikh Muhammad Arsyad Al-Banjari, a famous scholar at the time of the Kingdom of Banjar until now. His full name was $\mathrm{H}$ Abdussamad bin $\mathrm{H}$ 
Jamaludin bin Syekh Muhammad Arsyad Al-Banjari, born on 24 Zulqaidah 1237 AH (August 12, 1822 AD) in Penghulu Bakumpai Village or Marabahan. Every Ramadan month, clerics from Banjarmasin, Martapura and Upstream River areas came for a visit to learn the thariqat and join khalwat suluk under his instruction. He frequently visited villages throughout time, even to the interir areas of the Barito river, preaching the religion of Islam, so that many people of Dayak in the areas embraced Islam through his guidance (Maskuni, 2006: 35). The teachings of Abdussamad were characterized by the development of the thariqat Naqsyabandiyah with is suluk, and also thariqat Syadziliyah (Sadzali, 2006).

Upon the death of $\mathrm{H}$. Abdussamad, Islamic propagation was continued by his successors, the three brothers who were clerics in the region of Marabahan, Barito Kuala District namely: H. Sibawaihi better known as Haji Bawai, H. Kastalani dan H. Asqalani known as Haji Iwat. Islamic propagation was conducted at the home of $\mathrm{H}$. Bawai every Friday night in Marabahan and in addition he also founded Al Mujahiddin Boarding School at Marabahan. Bakumpai people received Islamic instruction by going to the Quranic recitation conducted at Marabahan, mainly by three religious figures above. Bakumpai people in Kuripan Sub-district, besides going to Marabahan for receiving religious instruction, were also visited by apreacher named Aspuri, who came from Kampung Bentuk in Marabahan who often visited villages in the Sub-District of Kuripan including Jambu Baru to teach Islam. Judging from his place of origin which was Marabahan, he was most likely a student of the descendants of $\mathrm{H}$. Abdussamad.

\section{THE MOSQUE AS A PLACE OF WORSHIP AND SOCIAL ACTIVITIES}

The mosque and the mushalla (small mosque) had a central role in the implementation of Islamic religious rituals for the Bakumpai. The five daily prayers are personal obligations, but the Friday prayer will be a concern when one is not present at the mosque on Friday. For Bakumpai people, Friday is highly appreciated, so they do not work all day. Mutual community activities are usually carried out on Friday afternoons as most citizens have spare time or reduce other activities on Fridays. There are restrictions of working called bentuk andau (at noon) on Fridays, especially at a time when a preacher is giving a sermon; (they believe that) if they work, they will be hurt; if they climb, a tree, they will fall. Friday is considered to be a special day, when the khatib (preacher) is giving his sermon, under the pulpit we often see bottles of water. After Friday prayers, the bottles are taken home for pregnant women to 
drink so that they will give birth to the child without problem.

Every Rabi' Al-Awwal month, the Bakumpai people celebrate the Birthday of Prophet Muhammad at the mosque. The activities are almost similar to any Friday because all the residents there are not working but going to the mosque to celebrate the Mawlid of the Prophet. The event usually starts in the morning around 8 am with each family bringing drinks and cake to the mosque while some parents especially religious leaders recite the Barzanji (prayer, praise and stories about Prophet Muhammad) accompanied by percussion music.

The melodic reading of barzanji may last several hours during which most residents returned to their respective homes and those staying at the mosque are mostly old people who are chanting poetry of Barzanji and some just come to listen. Meanwhile women are preparing food at home to take to the mosque. The peak of Mawlid celebration is when it comes to the end of the Barzanji reading when there is an announcement for the residents to come back to the mosque. The residents return with a variety of foods and then place them in the middle of the mosque. After everyone is present, the reading of barzanji resumes until it comes to the reading of "marhaban ya nurul aini" (welcome Nurul Aini) and everyone in the mosque stands up and reads the chant together. After the reading of barzanji is finished, they pray for safety, and then each family come together to enjoy foods they bring from home.

\section{TRADITION OF TULAK BALA IN THE MONTH OF SAFAR}

According to the beliefs of the Bakumpai people, in the month of Safar some bad guys release a bait/poison that may lead to diseases. The person who becomes ill is the sacrifice, especially as an attempt to get an affectionate husband or wife. To avoid the bait, one should be with careful when eating or drinking in public, because the bait could be put on drinks or food. If exposed to the bait, a person could be sick or throw up some blood directly on the scene.

In addition to being careful with food, the Bakumpai hold an event of tolak bala (repelling the evil) that is held every month of Safar to repel any form of evil by means of reading out the Qasidah Burdah. The activity is performed before sunset after praying 'ashr. First, residents gather at the upper part of the village. After a few dozen people gathered, the community elders and religious leaders stand at the front side while holding the burdah book. Then the reading of the burdah begins while walking around the village. Two to three people read the burdah from beginning to end, while the people following behind them recite only the opening phrase which reads "Maula ya shalli wa sallim 


\section{daiman abada,'Ala habibika khairil khalqi kullihimi"}

Along the way, more and more people will join the event of tulak bala, and more people will be reading the burdah. In the crowd, there is one person carrying a large tray to collect cake provided by residents of each house. At the other end side of the village, the women are waiting and preparing sugar water to eat with the cake. After the crowd reach the end of the village, people put up a mat in the middle of the village for them to sit and pray for safety. After that, they eat the cake together.

\section{EDUCATION AND RELIGIOUS SYMBOLS}

Islamic education is not only taught through formal education like schools but from an early age, mothers also teach shahada (profession that there is no God but Allah and that Muhammad is the Messenger of Allah) to their children. While getting her child to sleep inside a tuyang (swing), a mother would sing "La ilaha illallah muhammaddarrasulullah, tuyang timba palambai labu... ayun $d u d u$ anakku $d u d u, d u d u$ diakan dalam ayunan". The song is continuously sung until the child is asleep.

Then along with the increasing age of the child, before sleep, parents teach children to read and memorize short surah of the Qur'an called fatehah epat (Faatihah four) i.e. surah Al-Fatihah, Al-Ikhlas, Al-Falaq, An-Nas. After memorizing fatehah epat, then the child should continue to memorize Allahula (Qursy verses) because it is considered important to cultivate courage, not to be afraid of ghosts.

The teaching of Islam in particular is conducted by learning mangaji or reading the Quran, starting with learning to read Alifan (a text book for teaching Arabic alphabet). Children learn how to memorize the Arabic letters from Alif, $B a$, $\mathrm{Ta}$, and so on, after that they continue to learn the mahija (spelling) of the letters, and when alifan is completed, they are ready to learn mangaji (reading the Quran). To memorize the Arabic letters, teachers use local traditions such as daily activities on the river. For instance, the letter alif is likened to a stick, called peanut turus i.e. a wooden stick plugged into the ground so that the beans can grow on it. The letter $b a$ " " " is likened to a person diving under a boat; letter ta “ت”, two people on a boat; letter “ث”, three people riding a boat; nuun "ن" one person on a boat. The way Qur'an is taught shows the fact that the Holy Book is written in Arabic so that for those non-Arabs (even for some Arabs themselves) its meanings are not always clear and easy to understand. Therefore it opens for the possibility of the emergence of a highly variable definition (Ahimsa-Son, 2012: 258). 
Examples of this kind of instruction help children memorize the Arabic alphabet faster, since they correspond to their daily activities. Unfortunately this method is gradually disappearing because of the teachings of the Quran reading currently people to use books called Iqra and Al-Banjari that also contain a quick way to read the Quran.

In addition to instruction of Quran reading, parents also motivate their children by using fairy tale which tells about the day of resurrection where the world will be flooded. People can no longer take refuge at home or up a tree; there is no place to hold except on human waste; that's the fate of someone who cannot recite the Qur'an. For those who can recite the Quran, they will be safe because the Quran will become their ship and the tatunjuk (marker made from rattan) will become the pillar of light, thus they will be free from the torment of the day of judgement. To the, Bakumpai people, the Qur'an is more than just a scripture, so they need to store it carefully. In addition to cleaning up oneself before touching the Quran, one should also hold bahalarat if they unintentionally step over the Holy Book.

In addition to the Quran, in practicing religion, the Bakumpai people also attach pictures or posters inscribed with Allah and Muhammad and other Arabic calligraphy, pictures of the cities of Mecca and Medina where Kaaba and the tomb of Prophet Muhammad are found. The most common images mounted on the wall of the home of typical Bakumpai peaple are the shahada, a person saying prayer, and people performing Hajj. The pictures are hung on the wall of the living room, family room or places that could be seen by guests.

\section{FAITH}

The belief in God for the Bakumpai people is not only in shahada, but also in facing a problem, for example, when lifting heavy objects, expelling evil spirit from people who are possessed or treat illness. The Bakumpai people have a popular saying that goes, "asal ikau yakin, cukup baca bismillah beh tau kawa te" (As long as you believe, just simply by reading bismillah, you can do it). For example on the sick, by reading bismillah which means "in the name of Allah" and blowing it to the sick, they will recover.

The faith in the religion of Islam for Bakumpai people can be seen from three kinds of pattern of four i.e. fatehah epat (four Faatihah), empat malaikat (four angels), sahabat epat (four companions of Prophet Muhammad). Fatehah epat (Faatihah four) as already explained, is the basis of short Surah in the Quran for practical needs of prayer for example after reading Al-fatiha in the first part of prayer, they can continue with Surah An-Nas or Al-Falaq, then in the 
second part, after Al-Faatihah, then they read surah Al-Ikhlas.

The four angels of the ten whom are required to believe are Gabriel, Michael, Israfel and Izrail. sahabat epat (four companions of Prophet Muhammad)are the khulafaturrasyidin, i.e. the four companions who later became Caliph after the death of Prophet Muhammad: Abu Bakr, Umar, Uthman and Ali. Both the Angels and the four companions are very important for Bakumpai people to serve as rajah. The rajah uses Arabic script, where the name of Allah in a central position surrounded by four angels on four sides; and as for Prophet Muhammad, his name is in the middle and four companions were on four sides. The Rajah is usually hung on the wall of the house right above the front door, used for the safety of the residents of the house and repellant of disturbances or wicked spirits.

\section{THE LOCAL BELIEF}

The Bakumpai people know have local belief that there a relationship between humans, human and the supernatural beings, namely Datu, Taluh and Sahabat, and the consequences of the relationship. This section will explain that although Islam is strongly embraced by the Bakumpai people, local belief still exists in their culture.

As discussed above that the Bakumpai people have a pattern of four in their faith, i.e. fatehah epat (four Faatihah), empat malaikat (four angels), sahabat epat (four companions of Prophet Muhammad). The three elements of four have impact on the identity called "science to know yourself". As accounted below:

"Uluh jida maku mangatawani kungaie, sama beh dengan lanjung buang. Itah harus mangatawani, narai asal kunge, narai aran asli kungetuh, kueh andakaie petak asal Nabi Adam si huang kunge, dan narai aran petak jite. Alam semesta tuh ada si huang kunge ada matan andau huang kunge, matan andau ji bagerek dan ji jida bagerek, ada angin, ada danum, ada sungei, petak, wasi, wasi kuning, naraka, sorga uras ada si huang kunge itah kabuat. Yaweh ji jida katawan sorga huang kunge dan aran sorga te, ela harap ie mengkeme ji aran sorga. Jibril, Mikail, Izrail, Israfil ataupun Abu Bakar, Umar, Usman, Ali, samandeah-e ada si huang kunge ada ada arai-e masing-masing. Yaweh ji handak jagao, harus katawan narai aran asli Izrail pencabut nyawa, dan aran Saidina Ali ji asli-e. Harus katawan si kueh andakai-e si kungan itah. Ka'bah ada si huang kunge, yaweh katawan andakai-e dan aran asli-e, biar jida usah mandai Haji kan Makah, sama beh dengan mandai haji..."

(People who do not want to know themselves are like empty sacks. We should know our origin and our name. Where is the the origin of 
the land of Adam and what is inside ourselves and what is the name of the land? The universe is everything inside, there is a sun in ourselves, the sun that moves and one that does not, there are wind, water, rivers, soil, iron, yellow iron, hell, heaven --everything is within ourselves. Whoever does not know the heaven within themselves, and the name of heaven, they cannot hope to taste the heaven. Gabriel, Michael, Izrail, Israfel or Abu Bakr, 'Umar, Usman, Ali are all within ourselves; there is also the original name of each. Whoever wants to be strong must figure out what the original name of Izrail is and what the real name of Saidina Ali is, and should know where they lie within themselves. Kaaba also exist within ourselves. Who knows where it lies within oneself and the original name of the Kaaba though he doe not go on Hajj to Mecca, it is the same as the Hajj itself .... (Haderanie, n.d.: 14-15)

The explanation above is part of the local belief, the names of prophets, companions of Prophet and the angels, the Kaaba in Islam turn out to be have been influenced by local belief. Such belief is not delivered openly. It is surreptitious because of an undisclosed nature. Basically, this belief teaches that all things in nature exist in the human body; man is told to find them himself where they are and what their names are. This doctrine seems to know the other names of the things that have been known to people in general, for example, when looking at the sharp weapons, material is basically iron, so if people know the real name of the iron then they will be immune to those sharp weapons. So are the names of four angels and four companions that can be found within a person in a secret place and with a secret name; whoever knows it, he is going to be strong. This teaching is no longer included in the religious instruction, but is commonly found in the development of physical strength, i.e. the science of knowing oneself to achieve a perfection. It is no longer the means to achieve the encounter or union with God, but is used for other matters as well, such as to obtain supernatural powers (Sadzali, 2006). Nevertheless, it should be underlined that these beliefs show that in human beings are a model of the universe.

\section{THE UNSEEN WORLD}

In the unseen world, the Bakumpai people recognize three types of spirits named datu, taluh, and sahabat. They are considered to have a relationship with humans and may cause good and bad impacts resulting from such relationships. Datu is considered the ancestor who lives in the supernatural as a leader or a ruler. Datu is also considered to have a place in the nature for example in the forest, rice fields, rivers, heirlooms, houses, mosques, or 
football fields. Datu is considered to be caretaker of such places.

Datu can serve as the protector as well as an evil spirit. For example, at the time of opening a soccer field, people planted four chicken eggs on the four sides around the field. When the egg was being plant, they chanted the sentence "Tuh panginan akan ketuh, ela ingganggu ikih datu lah" (this food is for you, please do not disturb us, datu). The person who first got into rice field (lowland areas), or forest, before the activity started he asked for permission "Ikih dumah tuh datu ai, ela ingganggu anak ensu bagawi" (Datu, here we come, please do not disturb our children when they are at work). Such examples show that datu is regarded as the ruler of the supernatural that relates to the human world.

Datu is considered an ancestor or connects with people in the past, and also has evil nature. A sign of disturbance from Datu is that when there is a family member getting sick without reasons, it is called kapuhunan. For example, the case of Mida (19 years old) who had a child aged around 8 months. Her child continuously cried without a clear cause even after medical examination. Finally they remembered that they had not fed the ancestor's spirit from her husband's family. Then they acknowledged that they had not fed datu who became the ganan (caretaker) of the keris (dagger). They promised if their child recovered, they would give offerings to the caretaker of the Keris. Whether it was a coincidence or there were other factors, Mida's child soon recovered. Several similar cases were common in which families recognzed gaduhan batuh uluh (ancient people's spirit) and promised to feed the gaduhan in order not to torture the family anymore.

The above case shows that datu originally functioned to keep or protect the family, but due to the long period of not giing offerings, he (datu) would disrupt the family members so that people will remember him. Giving offerings to (datu) should include food or traditional cakes, namely: kakulih baputi bagula (a kind of cake), dodol kasirat (a kind of sweets), wajik, cucur, gaguduh (fried banana), gagatas, nasi pulut (sticky rice), sangkaruk, 3 boiled eggs, banana, ketupat, bua gayam, hanteluh karuang, sarikaya, sasagun. All offerings are given one plate each, some money is added, and put on a tray. The event of gaving offerings could be at night or during the day, depending on the quiet situation.

The implementation of offerings is carried out by people who are the community elders. The event begins with the burning of incense, while sowing red and yellow rice. At the time of giving offerings, someone will chant "Tuh bagian ketuh, balaku tarima. Bila ada kakurangan ei tuh duit ei tau beh ketuh mamili ei" (this is your part, datu, kindly accept it; If it is not enough, here is 
some money, please you buy it yourself). After that, the offerings are thrown into the river to feed the sea deity and Datu of crocodiles, but can also be eaten by people attending the event of batatenga (giving offerings).

Meanwhile, taluh is different from datu, although they both are unseen beings, taluh tends to disturb people. People who got disturbed by taluh can experience kapuhunan, kasarungan, and palasit. Kapuhunan is actually the same as the disorder suffered from the act of datu, but this happens because of human behavior that is considered to have disturbed a certain place, like cutting down a tree, peeing in the holes, etc. The effect of kapuhunan is that one will experience pain, and to eliminate it, offerings should be laid on the site. The offering given is not as much as that given to datu, one ancak of offerings in a rectangular shape the size of an adult's palm, made from banana peel and small bamboo rods. The offerings can be eggs, or other traditional foods, sometimes a glass of black coffee.

A person can also get a taluh not because of disruption, but it is the act of a person with evil magical power or teluh called palasit. People who are exposed to palasit can be seen from their eyes which are not focused, and look scary. If there are people trying to drive the palasit away, the victim affected will yell at them to ask them to go away even if the person is still outside the House. The victim will actually confront anyone with rude words. Palasit can be treated by reciting verses of the Qur'an and then the victim will be given a hidu (blown on the head and while verses of the Qur'an is being recited) or a sambur (water blown from someone's mouth), or pressing the ends of the fingers and the palm of the hand or the foot using onions or peppers. The cries of pain from taluh can be heard, sometimes he begs to stop being tortured and promised to come out while asking for some offerings.

A person possessed by palasit, but does not react when the palasit is being expelled, while verses of the Qur'an are being read, will be investigated whether he is just kidding. In one case, when numerous attempts at treating palasit were not successful, people returned to the medical efforts such as injecting some sedative drugs so that the sick could sleep. It worked because he was not exposed to palasit but experienced mental distress due to family problems.

In addition to datu and taluh, there is another unseen creature called sahabat who befriends humans, so he helps humans especially in the treatment of a sick person called badewa. Sahabat specifically communicates with only one person whose profession is a tabit (physician). In the village of Jambu Baru, there was a tabit who had three sahabat, named Batu Lingga, Kakahdamu dan Bintang Kurung, each with a different character. These sahabat came from the upstream Barito River i.e. the areas of Gunung Timang and Gunung 
Saringgading, located across from the town of Muara Teweh, North Barito District, Central Kalimantan province. These three sahabat will come when called on, especially at the time the badewa is carried out.

Badewa is performed by a tabit by calling on the sahabat. The implementation of badewa usually lasts for two nights. The first night is a diagnosis for people who need batatamba (treatment) and usually if there is one person needs batatamba, then others will join as well. On that first night, the tabit called on the sahabat to get into his body. The sign of the arrival of sahabat is that the home will shake or people can hear something falling on the roof of the house. With his head facing down, the tabit will look at the outside and be ready to accept the arrival of a friend into his body. When the tabit is possessed by sahabat, people who want to talk to the sahabat need an interpreter because instead of using the Dayak Bakumpai language, Taboyan language is used.

The sahabat will ask what purpose he is called on, and people will answer to treat illness. The next question from the sahabat, is the offerings to them, and people usually answer the question with the same question what the offerings they should give to the sahabat, because the offerings it depends from the type of the disease. The first night of the presence of a sahabat is like a doctor who comes to check on the patient's disease, and the doctor will mention what he needs to do the he treatment. After the sahabat know the kind of disease of the person who will perform batatamba and tells him the offerings should be provided for them, then it is the end of the event of the first night.

The second night is at the core of the badewa event, in which the offerings are already prepared; they include rice, coconut, brown sugar, some money, needles, nasi tumpeng with four colors: white, red, yellow, black; menyak rice (regular and sticky rice), eggs, grilled chicken, bananas, kakulih, tape, cucur, wajik and lamang (traditional cakes). Then tabit then called on the sahabat as they did on the first night, then one by one the sahabats got into body of the tabit. In addition to person who needs the batatamba, others are allowed to watch the event as long as they remain quiet. According to Uma Karmah (70 years old), people love watching the dialog with a sahabat, because they come up with different characters.

Batu Lingga (one of the names of sahabat) is temperamental, when he enters the tabit's body, he will stand with a stick that has been prepared and talk out loud and rude. Sometimes the interpreter had a fight with the sahabat, especially when the requirements for the offerings are not complete. Kakahdamu has soft voice, and he usually brings pet unseen dogs with him. At the time Kakahdamu comes, people are prohibited from exiting the house due to fear of kapuhunan which is caused by the dogs. The last sahabat that 
enters the tabit's body is Bintang Kurung. Among the three sahabats, he is the most clever at treating diseases.

The treatment is carried out in accordance with the level of difficulty of the disease, for example sometimes the patient needs usap (rubbed on certain parts of the body) sometimes they just need tiup (blown with air coming out of the tabit's mouth). If pain is severe, then the patient needs to be sucked up in place of pain, or using a small knife the area of the pain will be cut up and covered with black fabric. After the cut, the tabit will take something from the blood then place it on top of a banana leaf. The Tabit also gives out medicines to the sick. The trick is while being possessed by sahabat, he just puts his hand out the window, and then he pulls it back, he can get some fragrant oil, or fresh leaves.

The patient probably suspects that there might be intrigue in performing badewa, especially the manner of the tabit, but until now no one could prove it, after all the treatment is open for the people to see. Moreover, when the possessed by sahabat, the tabit is speaking in the Taboyan language, while in fact he does not know the language at all. There is a story about a patient who came from afar, according to the tabit, there were evil people who planted the patakan (magic item buried in the ground) under the house and he took the patakan away. When the patient returned to his home, he found the item in the place mentioned by the tabit earlier, and there were signs of digging.

\section{CONCLUSION}

In light the the above discussion, there are several important points to conclude. First, there has been a misunderstanding regarding the Bakumpai people who converted to Islam and no longer call themselves a Dayak. This case actually not only occurred to the Bakumpai people, but also to the Meratus Dayak, and Kenyah Dayak (Ibrahim et al., 1979; Riwut, 1993; David, 1997; Tsing, 1998; Maunati, 2004; Chalmers, 2006).

Second, the fact that the Bakumpai people are practicing Islam is clearly undeniable, as evidenced by the religious implementation and local beliefs still persist. The first and second points can explain the position of the Bakumpai as an 'estuary' of the encounter between the Dayak and Islamic traditions, as indicated by the following table: 
Table 1

Encounter between the Dayak and Islamic traditions

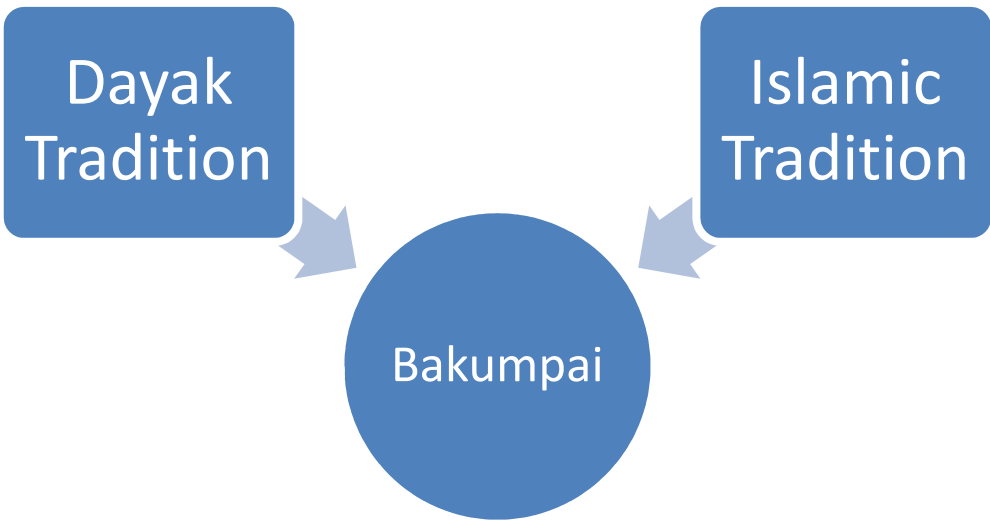

From the table above, the Bakumpai as part of the ethnic Dayak are clearly practicing the Dayak tradition either consciously or unconsciously. The use of the Bakumpai language which is also understood by most the Ngaju Dayak sub-group is very influential to the aspects of thinking, acting and behaving. Mystically, the Bakumpai people also believe in the unseen spirits ranging from ones that disturb humans to those who help people in the healing of diseases. Viewed from the Islamic tradition, the Bakumpai observe the pillars of Islamic obligations with various religious activities heavily influenced by the ethnic Banjar majority as the dominant Islamic adherents. The encounter between the Dayak and the Islamic traditions is manifested within the Bakumpai society. This pattern suggests that religion that works in the community, is a religion that is in the dialectic process with the values that can be found in the place, so inevitably the religion continues to changed both physically or rationally (Salehudin, 2007: 74-75). That is, the changes do not occur to the subject of religious teachings, but rather on the implementation of religious teachings that affect local traditions.

Third, religious differences practiced by members of ethnic groups is not to be seen as a difference but instead they should enrich local cultures. This is what is going on in the lives of the ethnic Dayaks in the religious diversity of the members of their ethnic groups.

\section{BIBLIOGRAPHY}

Ahimsa-Putra, HS., 2012. “The Living Al-Qur'an: Beberapa Persfektif Antropologi.” Walisanga. 20 (01). Mei. Hal. 257-260.

Daud, A., 1997. Islam dan Masyarakat Banjar Deskripsi dan Analisa Kebudayaan Banjar. Jakarta: PT RajaGrafindo Persada 
Haderanie, KH., (?) Ilmu Ketuhanan Ma' rifat, Musyahadah, Mukasyafah, Mahabbah (4M). Surabaya: Nur Ilmu.

Ibrahim, Sj. S, dkk., 1979. Bahasa Bakumpai, Jakarta: Pusat Pembinaan dan Pengembangan Bahasa Departemen Pendidikan dan Kebudayaan.

Kawi, Dj., 1985. Kamus Bakumpai Indonesia. Jakarta: Pusat Pembinaan dan Pengambangan Bahasa Departemen Pendidikan dan Kebudayaan.

Mahin, Marko., 2009. Kaharingan: Dinamika Agama Dayak di Kalimantan Tengah. Disertasi Doktor. Jakarta: Universitas Indonesia.

Maulani, Z.A., 2000. Demokrasi dan Pembangunan Daerah. Yogyakarta: Pustaka Pelajar dan CRDS

Maunati, Y., 2004. Identitas Dayak Komodifikasi dan Politik Kebudayaan. Yogyakarta: LKiS.

Maskuni, dkk., 2006. Sejarah Perjuangan Rakyat Barito Kuala. Marabahan: Pemerintah Kabupaten Barito Kuala Dinas Lingkungan Hidup, Kebersihan, Pariwisata dan Budaya.

Riwut, Tj., 1993. Kalimantan Membangun Alam dan Kebudayaan. Yogyakarta: Tiara Wacana.

Salehudin, Ahmad. 2007. Satu Dusun Tiga Masjid Anomali Ideologisasi Agaa dalam Agama. Yogyakarta: Pilar Media.

Sjamsuddin, H., 2001.Pegustian dan Temenggung, Akar Sosial, Politik, Etnis, dan Dinasti. Perlawanan di Kalimantan Selatan dan Tengah 18591906. Jakarta: Balai Pustaka.

Sadzali, A., 2006. "Perjumpaan Islam Tradisi Dan Dayak Bakumpai”. Makalah Annual Conference Kajian Islam di Lembang, Bandung. http://www. ditpertais.net/annualconference/ancon06/makalah/Makalah\%20 Ahmad\%20Syadzali.doc di akses tanggal 6 Juni 2007.

Tsing, A.L., 1998. Di Bawah Bayang-Bayang Ratu Intan: Proses Marjinalisasi Pada Masyarakat Terasing. Jakarta: Yayasan Obor Indonesia. 
